\title{
Egyptian journalists \\ and the struggle for \\ change following the \\ 20 I I uprising: The \\ ambiguous journalistic \\ agency between \\ change and conformity
}

\section{Fatima el Issawi}

Department of Literature, Film and Theatre Studies,

University of Essex, UK

\begin{abstract}
The Egyptian media displayed a high level of content diversity in the final years of the Mubarak regime, prior to the $201 \mathrm{I}$ uprising. This diversity expanded considerably after the uprising when national media embodied expressions of dissent with unprecedented openness, in defiance of the entrenched identity of the journalist as the regime's guard. This article investigates the dynamics of journalistic agency in Egyptian newsrooms in search for a new identity, investigating the challenges, hopes and trade-offs of a painful process of change. It looks at the complex interplay between these agentic dynamics and inherited structures within an uncertain and highly contested transition to democracy, which finally collapsed into a new chapter of authoritarianism. The article argues that while journalistic agency helped support trends towards democratization in media and politics in the immediate aftermath of the uprising, it also acted as powerful platform in 'othering' opponents preparing the ground for the return of autocratic practices and ultimately the fall of the democratic experiment.
\end{abstract}




\section{Keywords}

Agonism, change, conflicts, identity, journalism, practices, revolts

\section{Introduction}

The use of national media as a platform to denigrate dissent is a deeply rooted practice in Egypt. The nationalization of the press by President Gamal Abdel Nasser in 1956 transformed the national media into a platform at the service of the regime, enforced through various legal and administrative instruments. The state-owned national press - called as-Sahafa al-Qawmiyya - plays a crucial role in ensuring the media disseminates a unified voice in support of the regime by excluding and demonising dissent (el Issawi, 2014; Rizk and Atallah, 2011).

The immediate phase following the January 2011 uprising witnessed a trend within the community of traditional journalists chaotically searching for a new identity as they stepped away from their role as the regime's mouthpiece. This quest was empowered by the growing influence of social media as a news source for traditional newsrooms and the adoption by many traditional journalists of the blogger's personalized style, a trend which was obvious in several North African countries going through transitions or political reforms (Zayani, 2015). [AQ1] The hybrid identity of the journalist-activist that began to emerge contributed to a debate on the need for change in newsrooms' practices without leading to a formal review of professional practices. These chaotic 'revolts' against the direct or indirect political dictate were short lived, as they vanished with the military coup of July 2013, when journalists embraced their old habits of obedience to power.

The on-going clampdown on civil liberties in Egypt makes any attempt to change unlikely to succeed. According to civil society groups, as many as 40,000 people are being detained for political reasons as of 2016 (Freedom House, 2017). An alarming number of enforced disappearances by security forces continue to rise. According to a report by Amnesty International released in 2016, at least several hundred people, some as young as 14 years old, were abducted and tortured by security agents (Ismail, 2016). The media is facing an unparalleled crackdown: one example is the initiative of the government to provide citizens with telephone hotlines for reporting so-called 'false news', ahead of the latest presidential elections of March 2018, amid incitement against critical voices by framing criticism of the military as 'high treason' (Reporters Without Borders, 2018). The country's parliament has recently approved controversial constitutional amendments that would allow Sisi to stay in power until 2030, if endorsed by a popular referendum, while also granting the military extended powers over the judiciary and politics (BBC, 2019). At least 496 websites were blocked between May 2017 and February 2018, as per a report by an Egyptian NGO, the Freedom of Thought and Expression Law Firm (Al Jazeera, 2018). Egypt is the world's 
third largest jailer of journalists, with at least 20 behind bars (Committee to Protect Journalists, 2018).

\section{Egypt's news media: Structures of control}

Egyptian state media present a redundant and dysfunctional apparatus, with numerous print houses and a giant broadcast service, all managed by a heavy bureaucracy strongly linked to the executive power. The state-owned broadcaster (the Egyptian Radio and Television Union), the body of staff of which is estimated at no less than 40,000 persons, includes $30 \mathrm{TV}$ stations and nine radio networks, and is headed by the Minister of Information who directly oversees the management of the institution and appoints its high officials (ERTU Law, 1979). [AQ2]

Privately owned media was reintroduced first with the partisan press owned by political parties, and later through the outbreak of the so-called independent press in 2003 (privately owned by legal persons) and the launch of private satellite TV ventures in the same decade (Allam, 2012). The aftermath of the 2011 uprising witnessed the flourishing of a panoply of privately owned media projects, especially in the broadcast sector, without adopting a consistent regulatory framework for licensing. The sector was open to all political players, including the Islamists, without departing from the model of the media owners, the business tycoons connected to the regime by common interests. Recently, local media reported on new large media investments owned directly by the intelligence services. The company 'Eagle Capital' recently acquired a controlling stake in the prominent media house 'Egyptian Media Group', which owns several media companies in Egypt. According to an investigation by Mada Masr, one of few remaining independent media platforms in the country, 'Eagle Capital', headed by former Investment Minister Dalia Khorshid, is a private equity fund owned by the General Intelligence Service (Bahgat, 2018).

The Egyptian parliament has recently approved a new media law and three regulatory bodies reinforcing state control over traditional media and cyber space through new prohibitions on content aimed at silencing dissent or alternative media narratives (El-Sadany, 2018). The new law gives the regulatory bodies, strongly linked to the government, a broad prerogative in blocking content and websites, and open the door for the pursuit of journalists upon vaguely worded legal stipulations, such as disregard of national security and the defence of the country or incitement against the law (Amnesty International, 2018).

\section{Methodology and structure}

The article investigates the following research questions: how did journalists review or attempt to review their professional practices amid the chaotic opening of the political arena in the immediate aftermath of the 2011 uprising? How did these dynamics impact the journalistic agency as an important player in helping or in impeding the democratic change? How did these short-lived 'revolts' in newsrooms 
impact the entrenched identity of the regime's guard among journalists in state and private media and to what extent has this lead to radical and sustained change in practices among journalists or, at the contrary, encouraged the return to entrenched habits of obedience to politics?

The article draws on a series of 50 interviews conducted with Egyptian journalists working in the news media in the years that followed the 2011 uprising until the immediate phase after the military coup of July 2013. It is based on a thematic analysis of in-depth interviews that focused on the personal professional itinerary of each journalist and how they relate to their institutions, their professional practices and the political sphere. The interviews were semi-guided, as they followed a set of questions but left the window open for personal contributions from the interviewees to reflect on their career paths. These interviews are mostly face to face (some were conducted over the phone after the military coup when fieldwork in Egypt became difficult). The sample of journalists chosen reflects a balanced representation of the media industry, public and private, spanning radio, television and print. While one specific case study looks at the agentic power of journalists in state media in resisting alleged political dictate under the Brotherhood, other examples cover the experiences of journalists in the influential private media sector. The choice of journalists took also into consideration a balanced representation of male and female, senior and junior journalists.

The examples/case studies tackled in this article cover three important phases of the post-uprising in Egypt: the rule of the period of the Supreme Council of Armed Forces (SCAF) which witnessed important forms of rebellion against entrenched traditions of censorship in reporting on the army, the one-year Brotherhood presidency in which the issue of state media's independence was one of most important slogans in the opposition against their rule and finally the military coup of 2013 and its immediate aftermath when journalists embodied again old practices of obedience in the name of national interests and the fight against terrorism. While the second case looks at state media journalists' agency in challenging alleged control by the Brotherhood, as a form of journalistic but also political opposition, the third case focuses on the role played by privately owned media in fierce polarization during this exceptional parenthesis of openness and immediately after its fall with the military takeover in 2013.

Before delving into these case studies, I will first critically unpack the multiple and often ambivalent meanings and dynamics of agency as well as forms of political and business parallelism between media and politics with references to international case studies.

\section{The ambivalent journalistic agency}

Media's influence as an agent of change in a transitional process depends, to a large extent, on the complex dynamics between the structural preconditions of inherited systems on the one hand and the actors' agency for creating change on the other (Voltmer, 2013: 56). The intricate competition between structures and 
agency, as well as the constraints of the political transition, explain the ambivalence in journalists' perception of their roles in times of change, supporting reforms while also serving as a tool in the hands of powerful actors. While the media transformation is in itself one of the thorniest processes of institutional change, it is difficult to expect a successful transition to democracy without professional media that can hold the new elites to account.

Human agency has been defined according to various dimensions, mainly in terms of routine, intentionality and judgement. Major theories in understanding agency, such as the work of Pierre Bourdieu and Anthony Giddens, have given importance to the role of routinized practices. However, this intentional activity at the micro level cannot be understood independently from a system of interdependencies at the macro level, hence the complexity of its nature (Coleman, 1990). Normative approaches attempted to categorize the journalistic practice into professional models favouring an analysis based on structures. In their seminal work on comparative communication studies, Four Theories of the Press, Siebert et al. (1956) draw on four 'ideals' - typical models of journalism: authoritarian, libertarian, social responsibility and soviet communist. According to this normative categorization, the authoritarian model perceives the press as a tool for social stability whereby limiting pluralism is necessary to promote a unifying national narrative. This is in opposition with the liberal paradigm where media is expected to act as a provider of information and a forum for debate of ideas, enabling citizens to make their political choice freely (Curran, 2002). This categorization is criticized for its universalist and Western-centric focus, and its lack of empirical foundations. It is also perceived by scholars as failing to capture the complexities of the interplay between structures and agency in a fluid environment, such as the case of unpredictable processes of institutional change.

The wave of change that shook media and political structures after the 2011 uprising in Egypt witnessed the rise of an active agency among journalists in defence of journalistic rights and independence from governmental control. Like similar experiences affecting media in a regime change in Eastern Europe (see Milton, 2001; Price et al., 2002), this agency took the form of an extremely adversarial style, a specific genre of watchdog journalism based on the expression of individual subjectivity and critical views.

Interviews conducted with journalists in this case study confirm the value they give to the interventionist role they practiced amid the upheavals of an extremely troubled political change, largely perceiving themselves as informers of the public opinion rather than storytellers. While these journalists recognize the notion of a 'watchdog' function as an ideal of how professional journalism should be, they reject neutral watchdog journalism as incompatible with the specific contexts and structures in which their practices are taking place. The media's role as a platform for political messaging for ideological purposes becomes primordial during crucial crises when the notion of objectivity is challenged by contextual limitations (McQuail, 1992: 183-195). 
The journalistic ambivalence in the narratives of journalists interviewed, rejecting a Western approach to professional journalism while recognizing its importance, echoes Whitehead's (2002) distinction between the 'floating' and 'anchored' aspects of professional norms and standards: those essential for media to function, such as reporting a news story, and those that can be redefined or negotiated to fit within specific contexts. [AQ3] However, this ambivalent journalistic agency has equally ambivalent repercussions on the outcome of these fragile trajectories of change: while it helps foster political engagement by increasing citizens' knowledge of current issues (Newton, 1999), militant journalism deepens societal and political divides, making it difficult to reach a minimal agreement on the reality of the new regime (Mouffe, 2005).

\section{Media and political/business parallelism}

The centrality of media's role in politics has been the subject of much scholarly research (Cottle, 2006; Curran, 2002; Graber, 2007; Sparrow, 1999). Entman (1993) contends that through the functions of interpretation and framing, media allows some aspects of the perceived reality to be grounded and others ignored; arguing about a 'cascading activation' between media and politics (Entman, 2003), in which media frames activate elite policy decisions and vice versa. The news media's role in shaping political reality is even more important in constructing individuals' perceptions of a conflict. The media have become a crucial factor in transitional politics; mediatization of politics in emerging democracies is essential to understanding the complex trajectories of these movements (Voltmer, 2013; Wolfsfeld, 1997).

The limited research that was produced so far on the interplay between media and politics in the context of the Arab uprisings demonstrates that traditional news media acted as an active agent in destabilizing the new order by heavily disseminating a fear-mongering message, painting the transitions as an eminent danger to the nation's stability (el Issawi, 2016; Lynch, 2015). The concept of 'conflictsensitive journalism' was proposed as a possible solution to contain the effects of such inevitable polarization, by training journalists to adopt a conscious attitude about their responsibility to pacify conflicts without taking an advocacy role or preaching solutions (Howard, 2015). A conflict-sensitive journalist is described as one who 'applies conflict analysis and searches for new voices and new ideas about the conflict...takes no sides, but is engaged in the search for solutions' (Howard, 2015: 15). However, there are doubts as to how deeply this model can be realistically embraced by journalists framing and communicating conflicts resulting from the democratization processes in an environment of extremely heated polarization such as this Egyptian case study.

Egyptian journalists' account of their experiences and self-perception of practices discussed in this article reflect main features of political parallelism, a notion developed by Colin Seymour-Ure (1974) and revisited by Hallin and Mancini (2004, 2012) to describe a network of cosy relationships and complex alliances 
between media and political groups. This parallelism presented as the main feature of the polarized model, the dominant media system in southern European countries, can be explained by the strong tradition of considering the mass media as means of ideological and political mobilization (Brüggemann et al., 2014). Tumber (2007) argues that the media's tendency to mirror politics, especially in fractured societies, is the outcome of the lack of a clear identity for journalists as an independent professional community rather than purely ideologically leaning. In the same vein, the political context model proposed by Wolfsfeld (1997) contends that politics has more sway over the media than the media has over politics, thus the media's dependency on the political agenda.

However, the parallelism between journalists and political camps in the experiences of Egyptian journalists is not solely driven by ideological affinity but also by business clientelism; journalists became powerful actors in a network of interests whose logic is different from that of journalism. Their practices are impacted by a system of patron-client relationships whereby the complex and changing alliances between state bureaucracy and media owners largely define the media narratives (Sparks, 2008). The changing dynamics of these alliances make this parallelism inconsistent and ambiguous (Voltmer, 2013: 188). This model of parallelism between the powers in place and media owners is explained by the fact that the media barons use their investments in the field to pressure politicians in order to consolidate their interests. In Greece, where media ownership is equally used as a means to accumulate power, a traditional motto is 'give me a ministry or I will start a newspaper' (Papathanassopoulos, 1999). This parallelism, absorbed by journalists in their daily practices as the policy of the media institution, explains the ease with which they swiftly move from one political camp to another to secure the continuity of their media presence in tune with the nature of changes in the political sphere. The example of Al-Ahram's front page headline published the day after Mubarak's departure is instrumental. Having played a major role in denigrating protesters, describing them as thugs and traitors, Al-Ahram, a major state newspaper, celebrated Mubarak's departure by stating: 'The people have toppled the regime' (Shenker, 2011).

While acknowledged as an expected feature of transitional societies, scholars of democratization contend that excessive media-politics parallelism in tumultuous transitions has negative implications for democratic change. Opening up the media without a cultural change in the newsroom and without the establishment of independent regulatory bodies can turn the media into a platform for parochial interests, including sectarian agendas and hate speech, thus leading to a deeply polarized pluralism. It can also legitimize illiberal elites, allowing them to win electoral processes and potentially re-impose autocratic practices (Voltmer, 2013: 190-192). Importantly, polarized pluralism hinders the creation of agonistic public spaces in transitional contexts, in both political and media cultures. As Mouffe contends (2005), the main role of a democracy should be to revert antagonistic conflicts (whereby the ideological other is considered as an enemy that can be legitimately destroyed) into agonistic conflicts (whereby the other is seen as an 
adversary with the legitimacy to exist, but also to disagree with). Opening media to political allegiances, which can be rooted in sectarian and tribal bonds rather than ideological affinities, makes the task of building a shared national identity a difficult one.

However, this article does not in any way advocate for a depoliticized media environment neither for an automated translation of Mouffe' theory of agonistic pluralism into the Egyptian context. The article takes into consideration the fact that Mouffe's analysis is rooted in Western democracies where the dynamics of political and societal polarization take shape within established institutions and non-violent contexts while the Egyptian polarization led to victory of the unreformed remnants of the previous authoritarian regime that seized power by implementing a large-scale violent repression. The article uses Mouffe's analysis as a framework to understand some of the dynamics of political polarization intensified by media practices while giving full consideration to the specific features of the Egyptian context in the present and historically. It also takes into consideration the critique of Mouffe' agonistic pluralism, especially its ignorance of the importance of procedures that would help institutionalize and thus protect this pluralism (Benhabib, 1996). The lack of recognition of socioeconomic inequalities in the Third World countries as well as the weight of state bureaucracy and technocratic authoritarianism remain serious limitations to applying Mouffe' theory to nonWestern contexts (Kapoor, 2002: 479-480).

\section{Beyond 'Red Lines': Reporting on the military}

The rule of the SCAF, the military interim body, formed after Mubarak's departure in 2011, witnessed abhorrent violations of human rights, such as frequent violent crackdown on civilian protests, military trials of activists and the so-called 'virginity test' - a widespread abuse used against female activists, and torture in prisons - (Iskandar, 2012). However, this phase witnessed the growth of Egyptian journalists' agency as they became bolder in approaching strict red lines, without breaking from the culture of fear that surrounded dealings with the military institution. Most of journalists interviewed, from state and private media alike, described taking a cautious attitude in dealing with the military council while reflecting on tools and tricks they employed to escape such pressure. An example is the experience of a former deputy editor in chief of the official news agency (MENA), stressing that the publication of information on dissenting movements witnessed a significant rise in this phase, despite journalists' fear of the military:

Before, we used to ignore any news related to the demonstrations of civil movements. After the fall of the regime, we witnessed an unprecedented level of publishing news covering all street expressions. The relative red line was SCAF as we were reluctant to openly criticise the military council. But this was not as sacred as it used to be under Mubarak's regime. (March 2013, personal interview) 
In the meantime, the military generals deployed a PR campaign to seduce media by organizing regular briefs for senior journalists in an attempt to pre-empt any possible critical reporting using a carrot-and-stick policy. [AQ4] The description of these meetings by a prominent talk show host demonstrates the extent to which these meetings were able to influence journalists' perceptions:

SCAF invited some influential presenters and press editors. They met every one of us alone, they briefed us on on-going events. The aim was to provide us with accurate information so when we address our audiences we don't mess up and we avoid rumours on the military. I could understand the real role of secret services, the nature of their work and to what extent they are involved in everything. (March 2013, personal interview)

Despite the unprecedented openness in tackling various topics that used to be considered 'sensitive', airing criticism against the army remained a strict taboo, for fear of retaliation but also due to entrenched habits of 'respect' to the military institution that enjoys high levels of popularity among Egyptians. However, the revolutionary euphoria following Mubarak's departure facilitated an informal cultural change within newsrooms, including in reporting on the military's abuses, especially when these abuses are widespread and reported in international media. Moreover, the 'revolt' against the culture of red lines revealed an important generational divide between older and younger journalists, the latter eager to challenge the tendency to avoid sensitive topics that used to guide the editorial decisionmaking. This resistance reached even state-owned media. The experience of a junior reporter at the state-owned Nile TV is instructive. He describes the coverage by Nile TV of major violent clashes between demonstrators and security forces in November 2011 in which the state TV reporter dared to expose the brutality of the security forces, an unprecedented move for the state TV:

Our correspondent was not relying on the news provided by the official news agency as we used to do. He was in the street, when the police issued a communiqué saying that they did not use gunfire, our correspondent was reporting live showing the empty cartridge in streets. We were telling what we saw and not what we were told to say. (June 2012, personal interview)

Another example comes from the experience of a junior reporter for the Ashourouq independent newspaper covering a press conference in which female activists denounced being subjected to so called 'virginity tests' in a controversial case that arose under SCAF's rule. The fear of retaliation did not stop her from covering a polemic topic and fighting for the publication of her report. She recounts:

I attended a press conference during which women talked about a virginity test they were forced to take. I wrote an article but my piece was not published the next day. Nothing was published also in all newspapers. When I asked my editor for the reason 
behind not publishing my piece, I was told that people will not believe that the military police can do something like this. (March 2013, personal interview)

The testimony of this young journalist demonstrates informal connivance among editors to self-censor all topics that could be considered disrespectful to the military, to the extent of imposing a blackout on information. However, the abuse of female activists at the hands of the army became a subject of discussion on mainstream media, including national Egyptian media.

The informal change in newsrooms' culture led to unprecedented levels of publishing information traditionally labelled as 'sensitive' or 'unapproachable' by Egyptian journalists, including the elite journalists, those 'controllers' who exercise an editorial decision making on what is deemed to be publishable. Journalists' timidity decreased with the expansion of abuses under SCAF's rule and the coming forward of a few victims who dared to talk to international and regional media (Shafy, 2011). This courage was boosted by an environment of 'hypermedia' (Kraidy, 2007) allowed by the informal fall of taboos; the interconnectedness of new and old media platforms allowed news stories to be widely shared, thus galvanizing the growing competition among journalists (and their media) to publish exclusive information. However, far from garnering institutional support, this change was limited in scope and volatile at its best. It did not manage to challenge the ideals of 'responsible journalism' for Egyptian journalists in reporting on the sacred, including the military institution presented in the dominant media narratives as 'the saviour of the revolution', the one who stood with the 'People' against the dictator (Mubarak). A former editor-in-chief of a state-owned newspaper, who claims he played a role in the military's decision not to attack demonstrators during the January 2011 uprising, recounts, while showing me the inflammatory headlines in support of the army, the paper published in that period:

When the demonstrations became a reality in the streets of Cairo, I called my connections - in the military - and told them: you have to choose between siding with the people or siding with the Mubarak family. I told them this is our opportunity to get rid of them. (June 2012, personal interview)

The wave of boldness against red lines regressed when the identity of the journalist as the regime's guard resurfaced, strongly driven by the perceived 'dangers' against the State and the patriotic duty to support the army against 'enemies' including the revolutionaries.

\section{State media as a battlefield: 'Brotherhoodization' of media}

The election of a Brotherhood government in June 2012 in the first democratic elections in the history of the country reshaped the political and media landscape while unleashing a fierce struggle between the new rulers and the apparatus of civil servants loyal to the former regime - called the 'deep state' - and which remained 
resilient to change (Momani, 2013). The extraordinary and complex battle between the two camps took media platforms, state and private, as its main stage, demonstrating the central role of national media as a political institution. A major episode of this battle was the alleged quest of the Muslim Brotherhood's newly appointed government to control state media in order to use it for friendly messaging, in line with former practices, popularly known as the Brotherhoodization of the media (akhwanat al i'lam). This alleged control attempt became a major topic of debate on the future of state media as well as an opportunity to denigrate the new government (Ahram Online, 2012). It allowed journalists to display an active agency through organizing frequent rallies and sit-ins to protest the alleged attempt by the new government to hijack their newfound liberty. It was also an opportunity to challenge outdated structures through calling for a true public service media, a goal quite often translated in journalists' narratives as 'the media of the people'.

My research with journalists and managers with the state broadcaster demonstrates attempts by the new administration to discipline journalists using a mixture of sanctions and co-optation tools, challenged by unprecedented agency from journalists to resist this pressure. The attempts to rebel against the new order by journalists and staff were met by a set of sanctions implemented by the management, ranging from referral to Public Prosecution and administrative investigations to arbitrary salary deductions, suspension from work, prohibition of access to the workplace, cessation of a program or change of its identity (Rashwan, 2011). [AQ5] Journalists interviewed talked about a trend of lowering the tone of criticism in state media by limiting the representation of radical and critical voices. Alleged blacklists for personas non-grata were applied by journalists in their choices of programme guests, an initiative confirmed by the then-head of the news department:

If a guest is employing obscene expressions and using our platform to settle personal accounts, he cannot be a regular guest with us. I asked the staff to invite the wise people and the moderate voices; those who have constructive opinions that unite and not divide. (March 2013, personal interview)

However, journalists displayed unprecedented resistance to the attempt to control their practices, in various manners. An example is given by an editor in the state TV news department:

I interviewed by phone a revolutionary leader known to be vocal against the Muslim Brotherhood. The director of programmes was angry and asked me to choose a softer voice. I asked him to provide me with a list of unwanted guests. He will never put it on paper. (March 2013, personal interview).

State media under the Brotherhood's rule witnessed journalists notably resisting the higher management's editorial dictate. Journalistic agency was empowered by 
the importance given to state media reform as a major topic in the political reforms (Elshhati, 2012). However, this agency adopted an interventionist watchdog model, embedding the personalized and emotional style of bloggers. For instance, news anchor and former presidential candidate Bothina Kamel faced disciplinary action after she asked the state TV audience to 'stay tuned for the Muslim Brotherhood Bulletin' while reading the news, an indirect criticism of the news agenda led by stories on the government's activities (Maher, 2013).

Asked about this wave of intimidation, the then Minister of Information in the Brotherhood government Salam Abdel Makssoud argued:

In any media system, journalists and staff can be subject to investigation when they commit professional mistakes. A presenter for example praised a guest while he was expressing insults. This is not professional. Will this be accepted in western media? (Personal interview, March 2013)

While this journalistic agency took bold forms, it is questionable to frame the resistance expressed by state media journalists to the Brotherhood's control as an indicator of a genuine departure from the entrenched practices of serving the powers in place. The journalistic resistance to the then-new rulers, the Islamists, who were framed as the 'enemy from within' by the state media for decades, can be seen as an expression of journalists' loyalty to old elites against new comers whose legitimacy has been historically denied.

As slogans of change were replaced by those of stability after the military coup, journalists reverted to old habits of supporting the regime by silencing dissent. After the overthrow of the Brotherhood, journalists adapted again to editorial 'orders' in the name of 'exceptional' conditions and the need to support the state against terrorists. The testimony of a journalist in the state television exemplifies the strong return of their identity as guard of the regime:

After the announcement of the removal of Morsi, we celebrated the news, dancing on desks. We were happy to get rid of the Brotherhood. The pressure became stronger on what is allowed to say but we live with it and understand the need of applying such measures as the State is facing terrorism. (November 2013, personal interview)

\section{The new watchdog of politics}

The hybridity of practices in Egyptian journalism finds its roots stretching back long before the 2011 uprising (el Issawi, 2016; Sakr, 2012); journalists adapting to obedience to red lines in certain topics while challenging them in others. [AQ6] The journalistic boldness to red lines witnessed phases of expansion and retreat, according to the changes in the political sphere and the level of tolerance towards dissent allowed by this change. 
The new media watchdog of politics that flourished in this special parenthesis took the form of an adversarial critic turning media narratives into a cacophony of voices, in line with international experiences of media and political transitions (see Voltmer, 2013). Traditional journalists, including those in state media, expressed their subjectivity by identifying with political agendas while continually swinging between two conflicting models: the lapdog journalist with ideological friends and the attack dog journalist with ideological and political enemies. This nascent chaotic new watchdog status empowered journalists' self-perception as full players in the power struggle while also increasing the on-going political and societal polarization between supporters of the Brotherhood government and supporters of a civilian government, including those loyal to the former regime. Polarized media pluralism took fierce forms, including what the director of the now-extinct Misr 25 TV pro-Brotherhood station calls 'professional bias':

There is nothing called neutrality. This is a lie. There is a professional bias. In the second round of the presidential elections, I was biased to the candidate of the revolution (Morsi), in the name of patriotism. (June 2012, personal interview).

At the other side of the political spectrum, the editor-in-chief of Al-Watan newspaper, presumably close to the military institution and known for its staunch opposition of the Brotherhood, sees neutrality as a non-realistic choice. He comments:

This is a battle we did not choose. We were portrayed as evils: The spiritual leader of the Brotherhood called us the media of shame, the newspaper's offices were burned... (June 2012, personal interview)

Beyond the battle of views, smear campaigns raged based on rumours and unfounded accusations, especially the publication of 'confidential' documents that were never verified or investigated by journalists. So-called leaked documents, such as suspicious bank accounts for senior figures in the Brotherhood leadership or evidence of tax evasion for business projects owned by them were extensively debated across media platforms. The publication of these documents was amplified, re-published by news websites, the press and social media pages, as well as debated on talk show platforms, making them a powerful political tool for manipulation. A climate of mistrust and fear was looming, aggravating the public's suspicion towards the Brotherhood government, laying the groundwork for its demise.

The increasing use of unverified leaked information aggravated the confusion among journalists and their publics on what is news and what is rumour, as expressed by the then head of news services at CBC network, a prominent private televised network that was launched after the 2011 uprising:

The worst enemy of news is rumours. Most of the information we got from the government or the presidency is a denial of non-confirmed information reported by media. If we asked about official information to elucidate the story, we have no 
answer. We have to always deal with unfinished stories. (March 2013, personal interview)

The polarized media pluralism and its normalization in journalists' practices exacerbated the transition's uncertainty, preparing the terrain for the closure of the media landscape by empowering a popular perception of media freedom as a threat to the state's stability.

\section{Discussions/conclusions}

The Egyptian case study is an example of how media polarization impacted political polarization while being driven by it. The fragmented and chaotic media landscape that prevailed during this unique parenthesis of openness in the country's history was reflective of the society's fractures and divisions ignited by the shackles of former disciplines and loyalties. This short phase presented an invaluable opportunity for Egyptian journalists to develop active agency independent from politics. However, this sense of liberation was lived by journalists through fully engaging in the fierce power struggle between old and new elites, leading to a replication of the deep-rooted media dependency to politics. Far from acting as an independent actor, traditional media was deeply invested in the struggles of a wider system of interests and influences, while acting as a producer of meaning and narratives in this battle.

The experiences of journalists described in this article reflect a blend of political and business parallelism whereby journalists understand their bias as an expression of their loyalty to a 'mission', that of defining the new identity of the regime, saving the revolution or saving the state. Their alignment with political agendas was celebrated as a sign of their empowerment, a sort of 'awakening' that allowed them to nurture complex relations with political powers, this time on an equal footing, real or imagined. This bias allowed them to reclaim their role as citizens not independent from political polarization or neutral towards it in line with the notion of 'responsible journalism': defending the state against its enemies. This quest for a more confrontational relationship to political power was short lived; it did not lead to the formation of an independent identity, as this quest did not enjoy support from the new regime and the journalistic community alike. In line with Tumber's analysis on the lack of a sense of independent professional community, Egyptian journalists claimed their independence by a deeper dependency to political agendas. Eager to keep their privileges and further nurture them, their parallelism is a blend of political leaning and clientelist interest.

Egyptian journalists demonstrated an active agency for change in the immediate phase after the January 2011 uprising through intentionality and purpose. However, their experiences show the limits of such agency, situated within a complex system of interdependencies. The instrumentalization of the news media by the state, media owners and political agendas was not challenged in a systematic manner; the transition neither witnessed any serious attempt to review the 
regulatory structures that dominate the media sector, nor did it allow for a departure from the ownership model of the wealthy businessman investing in media to secure a political say and accumulate economic power. The recent move by the military intelligence to own media organizations directly without the help of middle men, the business tycoons, has consolidated the state control over media.

Media are not by nature democratic institutions or institutions of democratization. The description of the journalist as 'a walking paradox' (Nordenstreng, 1995) reflects the ambiguity surrounding defining the role of a journalist. This confusion is even greater in contexts where a struggle between old habits and new trends is not able to be resolved. The data from the fieldwork presented in this article confirm the negative effect an ambivalent journalistic agency can have on a volatile change process. For media to act as an institution for change, there is a need for professional routines and institutional practices that forge the identity of a watchdog of power. This role cannot take shape without a review of structures, especially the dubious relationships between media ownership and the powers in place.

The short-lived revolts enjoyed by Egyptian traditional journalists interviewed in this study, in their quest to redefine their practices, failed in bringing about lasting and meaningful change: they did not enjoy support from the new/old political elites but were rather cleverly manipulated to frame the period following the uprisings in ways suitable to their agendas. Instead of using this agency in order to further autonomy from the power by putting the foundations for an independent community of professionals, these 'romantic' revolts that strived for independence from the 'big brother', the regime's main control bodies, ended by consolidating the power of parochial agendas over media, exacerbating the journalistic dependency to politics and the networks of interests. In line with Wolfsfeld's paradigm of political contest, politics has gained even more sway on media, as a result of these 'revolts'.

The dynamic media space post uprising mirrored the unparalleled openness in the political sphere but was also shaped by political realities. To this, we can add the realities of inherited structures and their limitations for both politics and media and the imbalance of force between these structures, and the agentic power exercised by journalists. These structures witnessed a phase of instability after the uprising without leading to a meaningful reform. It is also important to stress that the transition to a new democratic rule in Egypt was extremely turbulent. The military coup in 2013 has stalled the process of democratization; the failure of the institution-building process aggravated the vulnerability of journalists in resisting the sway of social and political forces, including the hegemonic control of the military over media and the economy in general. The recent so called constitutional amendment giving the military full sway over politics and the judiciary make the margin of manoeuvre for genuine change almost impossible.

\section{Declaration of Conflicting Interests}

The author(s) declared no potential conflicts of interest with respect to the research, authorship, and/or publication of this article. 


\section{Funding}

The author(s) received no financial support for the research, authorship, and/or publication of this article.

\section{References}

Ahram Online (2012) Egypt TV presenters march on Tahrir to protest Islamist media 'domination'. Ahram Online, 9 December, 12.

Al Jazeera (2018) Egypt's jailed journalists: Numbers, 3 May, 18.

Allam R (2012) Egyptian television broadcast regulatory framework: Challenges and opportunities. Article 19, 20 September, 12.

Amnesty International (2018) Egypt: Proposed laws an assault on online freedoms. 2 July. Available at: www.amnesty.org/en/latest/news/2018/07/egypt-proposed-laws-an-assaulton-online-freedoms/ (accessed 10 April 2019).

Bahgat H (2018) Looking into the latest acquisition of Egyptian media companies by general intelligence. Mada Masr, 21 March, 18.

BBC (2019) Egypt constitutional changes could mean Sisi rule until 2030. BBC, 16 April, 19.

Benhabib S (1996) The democratic movement and the problem of difference. In: Benhabib S (ed.) Democracy and Difference: Contesting the Boundaries of the Political. Princeton, NJ: Princeton University Press, pp. 3-18.

Brüggemann M, Engesser S, Büchel F, et al. (2014) Hallin and Mancini revisited: Four empirical types of Western media systems. Journal of Communication 64(6): 1037-1065.

Coleman J (1990) Foundations of Social Theory. Cambridge, MA: Harvard University Press.

Committee to Protect Journalists (2018) Egypt arrests 3 local journalists in 24 hours. 6 April. Available at: www.cpj.org/2018/04/egypt-arrests-3-local-journalists-in-24-hours. php (accessed 10 May 2019).

Cottle S (2006) Mediatized Conflict. Maidenhead, UK: Open University Press.

Curran J (2002) Media and Power. London, UK: Routledge.

El Issawi F (2016) Arab National Media and Political Change. Basingstoke, UK: Palgrave Macmillan.

El Issawi F (2014) Egyptian media under transition: In the name of the regime ... In the name of the people? Report, POLIS, Media and Communications, London School of Economics, UK, May.

El-Sadany M (2018) Egypt's new media regulations: Legislating state control over information. The Tahrir Insitute for Middle East Policy. 7 June. Available at: www.timep.org/ commentary/analysis/egypts-new-media-regulations-legislating-state-control-over-infor mation/ (accessed 10 February 2019).

Elshhati F (2012) As Cairo Undergoes Democratic Transition, Media Remains at Center of Struggle for Control. Vienna, Austria: International Press Institute.

Entman R (1993) Framing: Toward clarification of a fractured paradigm. Journal of Communication 43(4): 51-58.

Entman R (2003) Cascading activation: Contesting the White House's frame after 9/11. Political Communication 20(4): 415-432.

ERTU Law. Law No 13 of Year 1979 on the Egyptian Radio and Television Union.

Freedom House (2017). Egypt profile. Freedom in the world 2017. Report. Available at: www.freedomhouse.org/report/freedom-world/2017/egypt (accessed 9 May 2019).

Graber DA (2007) Media Power in Politics. Washington, DC: CQ Press. 
Hallin D and Mancini P (2004) Comparing Media Systems: Three Models of Media and Politics. Cambridge, UK: Cambridge University Press.

Hallin D and Mancini P (eds) (2012) Comparing Media Systems Beyond the Western World. Cambridge, UK: Cambridge University Press.

Howard R (2015) Conflict-Sensitive Journalism: (r)evolution in media peacebuilding. In: Hoffmann J and Hawkins V (eds) Mapping an Emerging Field, Routledge Studies in Peace and Conflict Resolution. Communication and Peace. New York, NY: Routledge, pp. $62-75$.

Iskandar A (2012) Year of the ostrich: SCAF's media experiment. Jadaliyya, 1 November, 12.

Ismail A (2016) Hundreds face torture and enforced disappearance in Egypt: Amnesty. Reuters, 13 July, 16.

Kapoor I (2002) Deliberative democracy or agonistic pluralism? The relevance of the Habermas-Mouffe debate for third world politics. Alternatives 27: 459-487.

Kraidy, M (2007) Saudi Arabia, Lebanon and the changing Arab information order. International Journal of Communication 1: 139-156.

Lynch M (2015) Trashing transitions: The Arab media after the uprisings. Journal of Democracy 26(4): 90-94.

Maher A (2013) Egypt deeply polarised as Morsi marks first year. BBC, 27 June, 13.

McQuail D (1992) Media Performance: Mass Communication in the Public Interest. London, UK: SAGE.

Milton AK (2001) Bound but not gagged: Media reform in democratic transitions. Comparative Political Studies 34: 493-526.

Momani B (2013) In Egypt, 'Deep State' vs. 'Brotherhoodization.' Brookings, 21 August, 13.

Mouffe C (2005) On the Political. London, UK: Routledge.

Newton K (1999) Mass media effects: Mobilization or video malaise? British Journal of Political Science 29(4): 577-599.

Nordenstreng K (1995) The journalist: A walking paradox. In: Lee $\mathrm{P}$ (ed) The Democratization of Communication. Cardiff, UK: University of Wales Press, pp. 114-129.

Papathanassopoulos S (1999) The effects of media commercialization on journalism and politics in Greece. The Communication Review 3(4): 379-402.

Price ME, Rozumilowicz B and Verhul SG (eds) (2002) Media Reform: Democratizing the Media, Democratizing the State. London, UK; New York, NY: Routledge.

Rashwan NH (2011) Egypt's state media: Obstacles on the road to freedom of speech. Ahram Online, 4 August, 11.

Reporters Without Borders (2018) Egypt creates hotlines for citizens to report fake news, 14 March. Available at: www.rsf.org/en/news/egypt-creates-hotlines-citizens-report-fakenews (accessed 13 April 2019).

Rizk N and Atallah L (2011) Egypt's evolving media landscape: Access, public interest and control. In: Hawton D and Puddephat A (eds) A New Frontier, An Old Landscape. New York, NY: Ford Foundation, pp. 118-136.

Sakr N (2012) Social media, television talk shows, and political change in Egypt. Television \& New Media 14(4): 322-337

Seymour-Ure C (1974) The Political Impact of Mass Media. London, UK: Constable; Beverly Hills, CA: SAGE.

Shafy S (2011) Egyptian woman tells of 'Virginity Tests'. Speigel Online, 10 June, 11. 
Shenker J (2011) Egypt's media undergo their own revolution. The Guardian, 21 February, 11.

Siebert F, Schramm W and Peterson T (1956). Four Theories of the Press. Urbana, IL: University of Illinois Press.

Sparks C (2008) Media systems in transition: Poland, Russia, China. Chinese Journal of Communication 1(1): 7-24.

Sparrow BH (1999) Uncertain Guardians: The News Media As a Political Institution. Baltimore, MD: Johns Hopkins University Press.

Tumber H (2007) The media and international conflict: A theoretical overview. In: Nossek $\mathrm{H}$, Sreberny A and Sonwalkar P (eds) Media and Political Violence. Cresskill, NJ: Hampton Press, pp. 23-40.

Voltmer K (2013) The Media in Transitional Democracies. Cambridge, UK: Policy Press.

Whitehead L (2002) Democratization: Theory and Experience. Oxford, UK: Oxford University Press.

Wolfsfeld G (1997) Media and Political Conflict: News from the Middle East. Cambridge, UK: Cambridge University Press.

Zayani M (2015) Network Publics and Digital Contention. New York, NY: Oxford University Press. 